\title{
Improvement of Cutaneous Anaplastic Large Cell Lymphoma by Brentuximab Vedotin Monotherapy
}

\author{
Kutanöz Anaplastik Büyük Hücreli Lenfomada Brentuksimab Vedotin Monoterapisi ile Düzelme
}

\author{
(D) Takashi Onaka ${ }^{1}$, (D) Tomoya Kitagawa ${ }^{1}$, (D) Chika Kawakami², (D) Akihito Yonezawa ${ }^{1}$ \\ ${ }^{1}$ Kokura Memorial Hospital, Clinic of Hematology, Kitakyushu, Fukuoka, Japan \\ ${ }^{2}$ University of Occupational and Environmental, Department of Dermatology, Fukuoka, Japan
}

Brentuximab vedotin (BV) is an antibody-drug conjugate composed of a CD30-directed monoclonal antibody and monomethyl auristatin E [1]. BV monotherapy showed good response rates for cases of refractory and relapsed anaplastic large cell lymphoma (ALCL), but only a few case reportsare available for cutaneous localized ALCL (CALCL). We herein report the treatment with $\mathrm{BV}$ of relapsed $\mathrm{CALCL}$ with an excellent response. An 82-year-old female with relapsed CALCL had generalized erythema accompanied by desquamation and could not extend her fingers enough (Figure 1), with no lymph node lesions. Due to the previous treatment with radiation, steroid ointment, and systemic chemotherapy, we chose BV monotherapy for her, dosing at $1.8 \mathrm{mg} / \mathrm{kg}$ every 21 days. After the third infusion, her generalized erythemaand her finger movement were improved (Figure 2). She did not have any severe adverse effects or infusion reaction except for hematologic toxicity (leukocytopenia). She has finished 6 courses of BV infusion and maintained remission of skin lesions. There are several reports that showed the effectiveness of BV treatment for cALCL $[2,3]$, but the optimal treatment interval and cycles, and the necessity of maintenance therapy by using BV, are unclear. Further studies are needed to evaluate BV treatment in cases of cALCL.

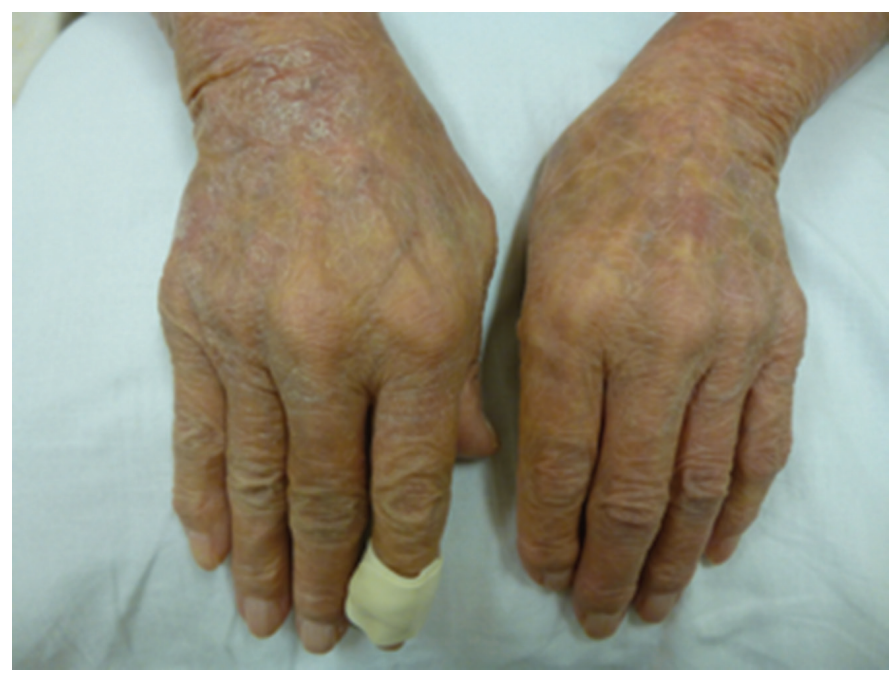

Figure 1. Generalized erythema accompanied by desquamation before treatment with brentuximab vedotin.

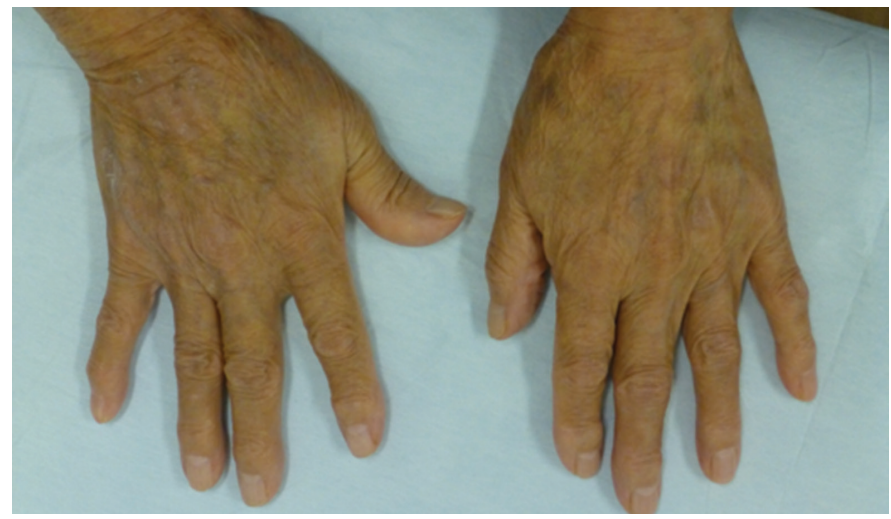

Figure 2. Improvement of skin erythema accompanied by desquamation after 4 cycles of brentuximab vedotin. 
Keywords: Brentuximab vedotin, Cutaneous ALCL

Anahtar Sözcükler: Brentuksimab vetodin, Kutanöz ABHL

Informed Consent: Informed consent was obtained from the patient.

Conflict of Interest: The authors of this paper have no conflicts of interest, including specific financial interests, relationships,and/or affiliations relevant to the subject matter or materials included.

\section{References}

1. Katz J, Janik JE, Younes A. Brentuximab vedotin (SGN-35). Clin Cancer Res $2011 ; 17: 6428-6436$.

2. Desai A, Telang GH, Olszewski AJ. Remission of primary cutaneous anaplastic large cell lymphoma after a brief course of brentuximab vedotin. Ann Hematol 2013;92:567-568.

3. Kaffenberger BH, Kartono Winardi F, Frederickson J, Porcu P, Wong HK. Periocular cutaneous anaplastic large cell lymphoma clearance with brentuximab vedotin. J Clin Aesthet Dermatol 2013;6:29-31. 